\title{
Breeding Vegetables with Improved Bioactive Properties
}

Mariola PLAZAS ${ }^{1)}$, Santiago VILANOVA ${ }^{1)}$, Isabel ANDÚJAR ${ }^{1)}$, Pietro GRAMAZIO ${ }^{1)}$, F. Javier HERRAIZ ${ }^{1)}$, M. Dolores RAIGÓN ${ }^{2}$, Salvador SOLER ${ }^{1)}$, Maria R. FIGÀS ${ }^{11}$, Adrián RODRÍGUEZ-BURRUEZO ${ }^{1)}$, Ana FITA ${ }^{11}$, Dionís BORRÀS ${ }^{1)}$, Jaime PROHENS ${ }^{1 *}$

1) Instituto de Conservación y Mejora de la Agrodiversidad Valenciana, Universitat Politècnica de València, Camino de Vera 14, 46022 Valencia, Spain.

2) Departamento de Química, Universitat Politècnica de València, Camino de Vera 14, 46022 Valencia, Spain.

${ }^{*}$ Coresponding author, e-mail: jprohens@btc.upv.es, mdraigon@qim.upv.es

Bulletin UASVM Horticulture 71(2) / 2014

Print ISSN 1843-5254, Electronic ISSN 1843-5394

DOI:10.15835/buasvmcn-hort:10295

\begin{abstract}
Vegetable crops contain significant amounts of many bioactive compounds which prevent and/or protect against chronic diseases. Consumers increasingly demand vegetables with improved bioactive properties and this is stimulating the development of new cultivars with enhanced content in bioactive compounds. Generally, breeding programmes of specific crops are aimed at increasing the most relevant bioactive compounds of each crop. The success of these breeding programmes depends on the availability of sources of variation for bioactive compounds. Traditional varieties and wild relatives collections are generally very variable for these compounds and in many cases it is possible to identify sources of variation of great interest among these materials. There are several breeding strategies for improving the content in bioactive compounds, including conventional strategies based on phenotyping, as well as modern strategies that rely on marker assisted selection or genetic transformation. Breeding for the enhancement of bioactive compounds may affect vegetables in a positive (e.g., extended shelflife) or negative (e.g., browning, bitterness) way other relevant traits for the success of a cultivar. The negative side effects may be circumvented by using complementary breeding strategies aimed at reducing or removing the negative impact on the characteristics and performance of a new cultivar. In summary, breeding can contribute to the development of a new generation of vegetable crops with enhanced bioactive properties and therefore to the development of the horticultural sector.
\end{abstract}

Keywords: antioxidants, breeding strategies, diversity, genetic improvement, marker assisted selection, new cultivars, wild relatives

\section{INTRODUCTION}

Many epidemiological studies reveal that people having a high level of consumption of vegetables presents a better health and lower risk of chronic diseases, including cardiovascular diseases and different types of cancer (Hung et al., 2004; Boeing et al., 2012). Vegetables contain many bioactive compounds and represent a major source of antioxidants and other compounds that are beneficial to human health (Terry, 2011; Rajarathnam et al., 2014). Consumers are increasingly demanding vegetables with bioactive properties that contribute to maintaining a good health and preventing diseases (Weatherspoon et al., 2014). In consequence, breeding programmes in vegetables are increasingly considering the content in bioactive compounds as a major breeding objective (Diamanti et al., 2011).

In manyvegetablecrops, breedingprogrammes have been devoted to improving yield, resistance to diseases, produce uniformity or apparent quality (Prohens and Nuez, 2008a, 2008b). Other important traits, like those related to organoleptic quality have generally been considered of second rank compared to breeding for yield, although in some crops breeding for organoleptic quality 
has also been considered an important trait in breeding programmes (Casañas and Costell, 2006). The content in bioactive compounds has been usually considered of low priority in breeding programmes, and few cultivars have been developed having dramatically improved contents in bioactive compounds. Among them, some new varieties have been released that are characterized (and are advertised as such) with a higher conent in bioactive compounds. Among them there are some prominent examples, like the 'Fashion' watermelon, which has a high content in lycopene and citrulline, the 'Lycomate' and 'Doublerich' tomatoes, which have, respectively, a high content in lycopene and vitamin C, the Almagro eggplant, with high contents in chlorogenic acid (Watada et al., 1986; Tarazona-Díaz et al., 2011; Hurtado et al., 2014). As a consequence of this increased content in bioactive constituents these vegetable varieties have a high added value and reach a higher price in the market.

Given the increased demandand by consumers for vegetables with increased content in bioactive compounds, researchers and breeders are developing new knowledge and tools for an efficient breeding of the content in bioactive compounds in vegetables (Cámara, 2006; Diamanti et al., 2011). In this way, there is an increasing number of breeding programmes and scientific studied aimed at improving the content in bioactive compounds of vegetables, and the trend seems that will continuing in the coming years. In this respect, the development of genomics is greatly contributing to improve marker assisted selection as well as to develop tools for an efficient breeding (Pérez-de-Castro et al., 2012).

In this paper we deal with some relevant issues related to breeding for the content in bioactive compounds in vegetables, including breeding objectives, diversity and sources of variation, breeding strategies, and collateral effects on other traits of interest for the success of a cultivar. The objective is provide general and comprehensive information for the development of vegetables with improved bioactive properties.

\section{BREEDING OBJECTIVES FOR IMPROVING BIOACTIVE PROPERTIES}

Plant breeding is aimed at exploiting the genetic potential of plants for benefit of humans (Rodríguez-Burruezo et al., 2009; Acquaah, 2012).
Therefore, breeding programmes aimed at improving the bioactive properties of vegetables will be devoted to developing new varieties with contents of bioactive compounds higher than those of the predominant varieties (Cámara, 2006; Diamanti et al., 2011). In this respect, breeding efforts can be devoted to improving a specific compound (e.g., chlorogenic acid, $\beta$-carotene, glucoraphanin, etc.), a group of compounds (e.g., total phenolics, total carotenoids, total glucosinolates, etc.), or an aggregate property (e.g., antixodant activity, anticarcinogenic activity, etc.). Each of these levels has different levels of complexity from the point of view of breeding. Breeding for specific compounds generally will be less complex from the genetic point of view than breeding for groups of compounds or aggregate properties, in which the genetic control is usually more complex (Rodríguez-Burruezo et al., 2009; Acquaah, 2012).

Within vegetable crops there are many compounds with bioactive properties, like phenolics, carotenoids, glucosinolates, vitamins, folates, phytosterols, etc. (Cámara, 2006; Rajaranthnam et al., 2014). However, each of these groups contain many compounds, and there are important differences in the activity of individual compounds within each group (Ignat et al., 2011; FernándezGarcía et al., 2012). Also, given that there are important differences among vegetables in the compounds responsiblefor the bioactive properties (Cámara, 2006; Tsao et al., 2006; Prohens and Nuez 2008a, 2008b), breeding programmes are usually directed to increasing the levels of those compounds or groups of compounds that are responsible of the most relevant properties for each vegetable crop (Table 1).

\section{DIVERSITY AND SOURCES OF VARIATION}

As occurs with any breeding programme, the success of a breeding programme for improving the bioactive properties of a vegetable crop requires having genetic diversity available for the target trait/s (Rodríguez-Burruezo et al., 2009; Diamanti et al., 2011; Acquaah, 2012). Identification of genetic diversity in collections of germplasm or populations for bioactive compounds can be done using conventional methods based on classical genetics and quantitative genetics methods or with modern biotechnologies (Rodríguez-Burruezo et 
al., 2012; Acquaah, 2012; Pérez-de-Castro et al., 2012).

As occurs with nutrients (e.g., carbohydrates, proteins, minerals, etc.) in which modern breeding has led to the undesirable effect of "dilution of nutrients" (Davis, 2009), for bioactive compounds there has also been a reduction in the levels in modern varieties when compared with traditional varieties. In this way, increases in yield have frequently been associated to a reduction in the content of compounds with bioactive properties. Similarly, the introduction of long shelf-life genes, which alter ripening, may produce a reduction in the content of bioactive compounds. In this respect, in the case of tomato, gene rin, which is present in many long shelf-life varieties of

Tab. 1. Some important vegetable crops and major bioactive groups of compounds and specific compounds for which breeding programmes are being performed.

\begin{tabular}{|c|c|c|}
\hline Vegetable crop & Compounds with bioactive properties & References \\
\hline $\begin{array}{l}\text { Artichoke (Cynara cardunculus var. } \\
\text { scolymus L.) }\end{array}$ & Phenolics, in particular chlorogenic acid & $\begin{array}{l}\text { Pandino et al. } \\
\text { (2012) }\end{array}$ \\
\hline Asparagus (Asparagus officinalis L.) & $\begin{array}{l}\text { Phenolics, in particular phenolic acids, } \\
\text { flavonoids, flavanols and ascorbic acid }\end{array}$ & Lee et al. (2014) \\
\hline $\begin{array}{l}\text { Cabbage and cauliflower (Brassica } \\
\text { oleracea L.) }\end{array}$ & $\begin{array}{l}\text { Glucosinolates, cartoenoids and } \\
\text { anthocyanins }\end{array}$ & $\begin{array}{l}\text { Padilla et al. } \\
\text { (2007) }\end{array}$ \\
\hline Carrot (Daucus carota L.) & $\begin{array}{l}\text { Carotenoids and phenolics, in particular } \\
\text { cholorogenic acid and anthocyanins }\end{array}$ & $\begin{array}{l}\text { Baranski et al. } \\
\quad(2012)\end{array}$ \\
\hline Celery (Apium graveolens L.) & Phenolics & Yao et al. (2010) \\
\hline Cucumber (Cucumis sativus L.) & Carotenoids, in particular $\beta$-carotene & $\begin{array}{l}\text { Navazio and Simon } \\
(2001)\end{array}$ \\
\hline Eggplant (Solanum melongena L.) & $\begin{array}{l}\text { Phenolics, in particular chlorogenic acid and } \\
\text { antocyanins }\end{array}$ & $\begin{array}{l}\text { Prohens et al. } \\
\quad(2007)\end{array}$ \\
\hline Leek (Allium porrum L.) & $\begin{array}{l}\text { Phenolics, lutein, } \beta \text {-carotene, ascorbic acid } \\
\text { and vitamin E }\end{array}$ & $\begin{array}{l}\text { Bernaert et al. } \\
\quad(2012)\end{array}$ \\
\hline Lettuce (Lactuca sativa L.) & $\begin{array}{l}\text { Carotenoids, in particular } \beta \text {-carotene and } \\
\text { lutein, and anthocyanins }\end{array}$ & Mou (2005) \\
\hline Melon (Cucumis melo L.) & Carotenoids & $\begin{array}{l}\text { Harel-Beja et al. } \\
\quad(2010)\end{array}$ \\
\hline Onion (Allium cepa L.) & $\begin{array}{l}\text { Phenolics, in particular flavonoids, flavonols and } \\
\text { anthocyanins, and ascorbic acid }\end{array}$ & Yang et al. (2004) \\
\hline Pepper (Capsicum annuum L.) & Carotenoids, phenolics, and ascorbic acid & $\begin{array}{l}\text { Rodríguez- } \\
\text { Burruezo et al. } \\
\quad(2011)\end{array}$ \\
\hline $\begin{array}{l}\text { Pumpkin, squash and zucchini } \\
\text { (Cucurbita spp.) }\end{array}$ & Carotenoids, tocopherol, ascorbic acid & $\begin{array}{l}\text { de Carvalho et al. } \\
\text { (2012) }\end{array}$ \\
\hline Spinach (Spinacia oleracea L.) & Lutein and phenolics & $\begin{array}{l}\text { Pandjaitan et al. } \\
\qquad(2005)\end{array}$ \\
\hline $\begin{array}{l}\text { Table beet (Beta vulgaris subsp. } \\
\text { vulgaris L.) }\end{array}$ & Betalains & $\begin{array}{l}\text { Gaertner et al. } \\
\quad(2005)\end{array}$ \\
\hline Tomato (Solanum lycopersicum L.) & $\begin{array}{l}\text { Carotenoids, in particular lycopene, phenolics, } \\
\text { and ascorbic acid }\end{array}$ & Adalid et al. (2010) \\
\hline $\begin{array}{l}\text { Watermelon (Citrullus lanatus } \\
\text { (Thunb.) Matsum. \& Nakai) }\end{array}$ & $\begin{array}{l}\text { Carotenoids, in particular lycopene, and } \\
\text { ascorbic acid }\end{array}$ & Yoo et al. (2012) \\
\hline
\end{tabular}


tomato (Marín, 2013), causes a reduction in the content in lycopene in the fruit (Vrebalov et al., 2002). This indicates that very often breeding programmes aimed at improving the bioactive properties of vegetables will need to identify sources of variation in materials other than élite modern varieties. Furthermore, modern varieties usually have a narrow genetic base (Simmonds, 1997; Rodríguez-Burruezo et al., 2009; Acquaah, 2012) and in order to improve the bioactive properties breeders very frequently will have to turn to materials like traditional varieties and wild relatives.

Traditional varieties usually present a high variation for the content in bioactive compounds, which values much higher than those of modern commercial varieties (Koch and Goldman, 2005; Mou, 2005; Rodríguez-Burruezo et al., 2005; Burger et al., 2006; Prohens et al., 2007; PerkinsVeazie et al., 2010). Traditional varieties have the advantage that hybridizations with modern élite materials are fertile and hybrids and subsequent generations present the typical characteristics of the domesticated species (Rodríguez-Burruezo et al., 2009). On occasion, related wild species represent an additional source of variation of great interest as they present values much higher (frequently several times higher) than those present in the cultivated species (Willits et al., 2005; Prohens et al., 2013). However, in these cases, breeding programmes can encounter some difficulties in hybridization, hybrid sterily or reduced fertility, and the need of high number of backcross generations to remove the undesirable part of the genetic background of the donor wild relative (Kalloo and Chowdhury, 1992; RodríguezBurruezo et al., 2009). In any case, the availability of adequate sources of variation usually requires the screening of large germplasm collections in order to identify materials of interest (RodríguezBurruezo et al., 2005; Prohens et al., 2007). Once these sources of variation have been identified, an adequate and efficient breeding strategy has to be applied in order to introgress it into an appropriate genetic background in order to obtain a commercially valuable cultivar (Simmonds, 1997; Rodríguez-Burruezo et al., 2009; Acquaah, 2009).

\section{BREEDING STRATEGIES}

Although some bioactive properties of specific vegetable crops may be qualitative (i.e., presence/ absence), in most cases the traits responsable of the bioactive properties are quantitative. Also, apart from genetic differences, the high environmental influence in the expression of this type of traits favours the existence of continuous variation, even when the trait has an oligogenic control (Tsao et al., 2005). This implies that usually strategies for breeding for bioactive properties are those used for quantitative traits. Depending on the type of strategy to be used we can distinguish between conventional strategies based on phenotyping, marker assisted selection, and strategies derived from genetic transformation (Gepts, 2002; Collard and Mackill, 2008).

Conventional strategies are based on selection in genetically variable populations for the trait of interest and on hybridization and selection in segregating generations (Rodríguez-Burruezo et al., 2009; Acquaah, 2012). The success of plant breeding in the XXth centtury have mostly relied on these conventional strategies, which have proved highly successful and efficient for yield traits (Pérez-de-Castro et al., 2012). Application of these breeding methods to traits related to bioactive properties shows that for these traits it is posible to achieve important genetic advances. For example, we have found that in eggplant the narrow-sense heritability for total phenolics was of 0.5 (Prohens et al., 2007), which together with the wide diversity for this trait in the germplasm collections indicates that it is possible to achieve considerable genetic advances for this trait (Plazas et al., 2013).

The increasing availability of molecular and genomic tools is fostering, as occurrs with other traits, a revolution in breeding for bioactive properties (Pérez-de-Castro et al., 2012). In this way, thanks to the new developments it has been posible to identify quantitative trait loci (QTL) as well as genes and allelic variants of these genes involved in the synthesis of compounds responsible for bioactive properties as well as molecular markers linked to them (Just et al., 2009; Kinkade and Foolad, 2013a; Sotelo et al., 2014). This makes feasible in vegetable crops the marker assisted selection for traits related to bioactive properties (Kinkade and Foolad, 2013b; Plazas et al., 2013). Therefore, once the genes or QTL involved in 
the target bioactive compound/s are identified selection can be done of the individuals of interest without the need of phenotyping (Collard and Mackill, 2008). This strategy can also be very useful for gene pyramiding for different favourable alleles involved in the biosynthetic pathways of the target compounds (Ishii and Yonezawa 2007a, 2007 b; Plazas et al., 2013).

The improvement in the content of bioactive compounds can also be achieved by means of genetic transformation, which allows important increases in a short period of time (Díaz de la Garza et al., 2007; Guo et al., 2012). Genetic transformation requires the introduction using different transformation techniques of one or several genes from different organisms in the genome of the target species in order to achieve transgenesis (Kole et al., 2010). However, transgenic varieties are suffering from an important rejection at the social level and it seems difficult that they represent at a short-medium term a realistic alternative for the development of commercially accepted variaties, at least in Europe (nicolia et al., 2014). Cisgenesis, which consists in the genetic transformation resulting only in the introduction of genes obtained from materials sexually compatible with the donor variety (Jacobsen and Schouten, 2007), is an alternative that is free from most of the critics of transgenesis. However, given that cisgenesis uses genetic transformation techniques its utilization is not free of criticism and it is unlikely that it becomes approved soon in Europe.

\section{EFFECTS OF BREEDING FOR BIOACTIVE PROPERTIES ON OTHER TRAITS}

The success of a new cultivar requires that all the actors involved in the chain that goes from the production to the consumer become satisfied with the performance of the new variety (Rodríguez-Burruezo et al., 2009; Acquaah, 2012). In this respect, the improvement in the content of bioactive compounds, apart from an increase in the compound/s of interest may have other colateral effects, which can be positive or negative, on other agronomic or quality traits that may affect the success of the new cultivar.

An example of a positive effect is the increase in the shelf-life of tomato fruits with high levels of anthocyanins in the fruit (Zhang et al., 2013). In this respect, the antioxidant properties of many bioactive compounds may have a role in extending shelf-life, as they are able to neutralize the free radicals that are generated during the periods of senescence or as a consequence of infection (Davey and Keulemans, 2004; Singh et al., 2010; Zhang et al., 2013). Regarding negative effects, the increase in phenolics content can result in an increase of browning in vegetables like artichoke or eggplant (Prohens et al., 2007; Cefola et al., 2012). However, selection of allelic variants of polyphenol oxidases (necessary for the development of enzimatic browning) with reduced activity makes possible the selection of varieties with high content in phenolics and low browning (Plazas et al., 2013; Chi et al., 2014). Another example of a negative effect associated to the increase in bioactive compounds corresponds to glucosinolates, which have a bitter flavour, in brassicas (Drewnowski and Gomez-Carneros, 2000). In this case, the perception of the bitter flavour for different glucosinolates is different (Williams and Pun, 2010), and with positive selection for glucosinolates with low bitterness and negative selection for glucosinolates with high bitterness it might be possibile to improve the content in glucosinolates without increasing bitterness (Wricke and Weber, 1986). These two examples show that there are strategies that allow combining an increase in the content in compounds with bioactive properties and reduce the undesirable effects on other traits important for the success of a cultivar.

\section{CONCLUSIONS}

Breeding for bioactive properties in vegetables is increasingly becoming important in breeding programmes in vegetable crops. There are many bioactive compounds in vegetables and, therefore, there are many possibilities for the development of new cultivars with improved bioactive properties. The utilization of a wide diversity in breeding programmes, in particular from traditional varieties and wild relatives, on which applying adequate strategies for increasing the content of bioactive compounds will lead to the development of new vegetable crops cultivars with improved bioactive properties compared to present cultivars. At the same time, these strategies will strengthen the positive effects of the increase in these bioactive compounds on other traits of agronomic or comercial interest 
and to reduce the negative effects that may have on other characteristics. In summary, breeding for bioactive properties will allow the development of a new generation of cultivars with improved bioactive properties.

Acknowledgments. This project has been funded by Ministerio de Economía y Competitividad grant AGL2012-34213 and by Conselleria d'Educació i Esport de la Generalitat Valenciana (grant ACOMP/2014/191). Pietro Gramazio is grateful to Universitat Politècnica de Valencia for a predoctoral fellowship.

\section{REFERENCES}

1. Acquaah G (2012). Principles of plant genetics and breeding, Wiley-Blackwell, Chichester, UK.

2. Adalid AM, Roselló S and Nuez F (2010). Evaluation and selection of tomato accessions (Solanum section Lycopersicon) for content of lycopene, $\beta$-carotene and ascorbic acid. J. Food Comp. Anal. 23:613-618.

3. Baranski R, Allender C and Klimek-Chodacka M (2012). Towards better tasting and more nutritious carrots: Carotenoid and sugar content variation in carrot genetic resources. Food Res. Intl. 47:182-187.

4. Bernaert N, de Paepe D, Bouten C, de Clerq H, Stewart D, van Bockstaele E, de Loose M and van Droogenbroeck B (2012). Antioxidant capacity, total phenolic and ascorbate content as a function of the genetic diversity of leek (Allium ampeloprasum var. porrum). Food Chem. 134:669677.

5. Boeing H, Bechthold A, Bub A, Ellinger S, Haller D, Kroke A, Leschik-Bonnet E, Müller MJ, Oberritter H, Schulze M, Stehle P and Watzl B (2012). Critical review: vegetables and fruits in the prevention of chronic diseases. Eur. J. Nutr. 51:637-663.

6. Burger Y, Sa'ar U, Paris HS, Lewinsohn E, Katzir N, Tadmor $Y$ and Schaffer AA (2006). Genetic variability fro valuable fruit quality traits in Cucumis melo. J. Agric. Food Chem. 54:233-242.

7. Cámara M (2006). Calidad nutricional y salud. In: Llácer, G, Díez MJ, Carrillo JM and Nuez F (eds.), Mejora genética de la calidad. Ed. Universitat Politècnica de València, Valencia, Spain, pp. 43-65.

8. Casañas F and Costell E (2006). Calidad organoléptica. In: Llácer G, Díez MJ, Carrillo JM and Nuez F (eds.), Mejora genética de la calidad. Ed. Universitat Politècnica de València, Valencia, Spain, pp. 19-41.

9. Cefola M, D’Antuono I, Pace B, Calabrese N, Carito A, Linsalata V and Cardinali A (2012). Biochemical relationships and browning index for assessing the storage suitability of artichoke genotypes. Food Res. Intl. 48:397-403.

10. Chi, Bhagwat MB, Lane WD, Tang GL, Su YQ Sun RC, Oomah BD, Wiersma PA and Xiang Y (2014). Reduced polyphenol oxidase gene expression and enzymatic browning in potato (Solanum tuberosum L.) with artificial microRNAs. BMC Plant Biol. 14:62.

11. Collard BCY and Mackill DJ (2008). Marker-assisted selection: an approach for precision plant breeding in the twenty-first century. Phil. Transact. Royal Soc. B: Biol. Sci. 363:557-572.

12. Davey MW and Keulemans J (2004). Determining the potential to breed for enhanced antioxidant status in Malus: mean inter- and intravarietal fruit vitamin C and glutathione contents at harvest and their evolution during storage. J. Agric. Food Chem. 52:8031-8038.

13. Davis DR (2008). Declining fruit and vegetable nutrient composition: What is the evidence. HortScience 44:15-19.

14. de Carvalho LMJ, Gomes PB, Godoy RLD, Pacheco S, do Monte PHF, de Carvalho JLH, Nutti MR, Neves ACL, Vieira ACRA and Ramos SRR (2012). Total carotenoid content, $\alpha$-carotene and $\beta$-carotene, of landrace pumpkins (Cucurbita moschata Duch): A preliminary study. Food Res. Intl. 47:337-340.

15. Diamanti J, Battino M and Mezzetti B (2011). Breeding for fruit nutritional and nutraceutical quality. In: Jenks, M.A. and Bebeli, P.J. (eds.), Breeding for fruit quality. John Wiley \& Sons Inc., Hoboken, NJ, USA, pp. 61-80.

16. Díaz de la Garza RI, Gregory III JF and Hanson AD (2007). Folate biofortification of tomato fruit. Proc. Natl. Acad. Sci. USA 104:4218-4222.

17. Drewnowski A and Gomez-Carneros C (2000). Bitter taste, phytonutrients, and the consumer: a review. Amer. J Clinical Nutr. 72:1424-1435.

18. Gaerntner VL and Goldman IL (2005). Pigment distribution and total dissolved solids of selected cycles of table beet from a recurrent selection program for increased pigment. J. Amer. Soc. Hort. Sci. 130:424-433.

19. Gepts P (2002). A comparison between crop domestication, classical plant breeding and genetic engineering. Crop Sci. 42:1780-1790.

20. Guo F, Zhou W, Zhang J, Xu Q and Deng X (2012). Effect of citrus lycopene $\beta$-cyclase transgene on carotenoid metabolism in transgenic tomato fruits. PLoS ONE 7:e32221.

21. Harel-Beja R, Tzuri G, Portnoy V, Lotan-Pompan M, Lev S, Cohen S, Dai N, Yeselson L, Meir A, Libhaber SE, Avisar E, Melame T, van Koert P, Verbakel H, Hofstede R, Volpin H, Oliver M, Fougedoire A, Stahl C, Fauve J, Copes B, Fei Z, Giovannoni J, Ori N, Lewinsohn E, Sherman A, Burger J, Tadmor Y, Schaffer AA and Katzir N (2010). A genetic map of melon highly enriched with fruit quality QTLs and EST markers, including sugar and carotenoid metabolism markers. Theor. Appl. Genet. 121:511-533.

22. Hung HC, Joshipura KJ, Jiang R, Hu FB, Hunter D, SmithWarner SA, Colditz GA, Rosner B, Spiegelman D and Willett WC (2004). Fruit and vegetable intake and risk of major chronic disease. J. Natl. Cancer Inst. 96:1577-1584.

23. Hurtado M, Vilanova S, Plazas M, Gramazio P, Andújar I Herraiz FJ, Castro A and Prohens J (2014). Enhancing conservation and use of local vegetable landraces: the Almagro eggplant (Solanum melongena L.) case study. Genet. Resour. Crop Evol. 61:787-795. 
24. Ishii $\mathrm{T}$ and Yonezawa $\mathrm{K}$ (1997a). Optimization of the marker-based procedures for pyramiding genes from multiple donor lines: I. Schedule of crossing between the donor lines. Crop Sci. 47:537-546.

25. Ishii T. and Yonezawa K (1997b). Optimization of the marker-based procedures for pyramiding genes from multiple donor lines: II. Strategies for selecting the objective homozygous plant. Crop Sci. 47:1878-1886.

26. Jacobsen E and Schouten HJ (2007). Cisgenesis strongly improves introgression breeding and induced translocation breeding of plants. Trends Biotechnol. 25:219-223.

27. Just BJ, Santos CAF, Yandell BS and Simon PW (2009). Major QTL for carrot color are positionally associated with carotenoid biosynthetic genes and interact epistatically in a domesticated x wild carrot cross. Theor. Appl. Genet. 119:1155-1169.

28. Kalloo G and Chowdhury JB (1992). Distant hybridization of crop plants, Springer-Verlag, Berlin, Germany.

29. Kole C, Michler C, Abbott AG and Hall TC (2010). Transgenic crop plants - Volume I: Principles and development, Springer, New York, NY, USA.

30. Kinkade MP and Foolad MR (2013a). Validation and fine mapping of lyc12.1, a QTL for increased tomato fruit lycopene content. Theor. Appl. Genet. 126:2163-2175.

31. Kinkade MP and Foolad MR (2013b). Genomicsassisted breeding for tomato fruit quality in the nextgeneration omics age. In: Varshney, R.K. and Tuberosa, R. (eds.), Translational genomics for crop breeding. Volume II: Abiotic stress, yield and quality. John Wiley \& Sons, Hoboken, NJ, USA, pp. 193-210.

32. Koch TC and Goldman IL (2005). Relationship of carotenoids and tocopherols in a sample of carrot-color accessions and carrot germplasm $R p$ and $r p$ alleles. J. Agric. Food Chem. 53:325-331.

33. Lee JW, Lee JH, Yu IH, Gorinstein S, Bae JH and Ku YG (2014). Bioactive compounds, antioxidant and binding activities and spear yield of Asparagus officinalis L. Plant Foods Human Nutr. 69:175-181.

34. Marín J (2013). Portagrano: vademecum de semillas variedades hortícolas, José Marín Rodríguez, El Ejido, Spain.

35. Mou B (2005). Genetic variation of beta-carotene and lutein contents in lettuce. J. Amer. Soc. Hort. Sci. 130:870876.

36. Navazio JP and Simon PW (2001). Diallel analysis of high carotenoid content in cucumbers. J. Amer. Soc. Hort. Sci. 126:100-104.

37. Nicolia A, Manzo A, Veronesi F and Rosellini D(2014). An overview of the last 10 years of genetically engineered crop safety research. Crit. Rev. Biotechnol. 34:77-88.

38. Padilla G, Cartea ME, Velasco P, de Haro A and Ordás A (2007). Variation of glucosinolates in vegetable crops of Brassica rapa. Phytochemistry 68:536-545.

39. Pandino G, Lombardo S and Mauromicale G (2011). Chemical and morphological characteristics of new clones and commercial varieties of globe artichoke (Cynara cardunculus var. scolymus). Plant Foods Human Nutr. 66:291-297.

40. Pandjaitan N, Howard LR, Morelock T and Gil MI (2005). Antioxidant capacity and phenolic content of spinach as affected by genetics and maturation. J. Agric. Food Chem. 53:8618-8623.

41. Pérez-de-Castro AM, Vilanova S, Cañizares J, Pascual L, Blanca JM, Díez MJ, Prohens J and Picó B (2012). Application of genomic tools in plant breeding. Curr. Genom. 13:179-195.

42. Perkins-Veazie P (2010). Cucurbits, watermelon, and benefits to human health. Acta. Hort. 871:25-32.

43. Plazas M, Andújar I, Vilanova S, Hurtado M, Gramazio P, Herraiz FJ and Prohens J(2013). Breeding for chlorogenic acid content in eggplant: interest and prospects. Not. Bot. Horti Agrobot. Cluj-Napoca 41(1):26-35.

44. Prohens J and Nuez F (2008a). Handbook of plant breeding: Vegetables I, Springer, New York, NY, USA.

45. Prohens J and Nuez F (2008b). Handbook of plant breeding: Vegetables II, Springer, New York, NY, USA.

46. Prohens J, Rodríguez-Burruezo A, Raigón MD and Nuez F (2007). Total phenolics concentration and browning susceptibility in a collection of different varietal types and hybrids of eggplant: implications for breeding for higher nutritional quality and reduced browning. J. Amer. Soc. Hort. Sci. 132:638-646.

47. Prohens J, Whitaker BD, Plazas M, Vilanova S, Hurtado M, Blasco M, Gramazio P and Stommel JR (2013). Genetic diversity in morphological characters and phenolic acids content resulting from an interspecific cross between eggplant (Solanum melongena) and its wild ancestor $(S$. incanum). Ann. Appl. Biol. 162:242-257.

48. Rajarathnam S, Shashirakha MN and Mallikarjuna SE (2014). Status of bioactive compounds in foods, with focus on fruits and vegetables. Critical Rev. Food Sci. Nutr.: in press.

49. Rodríguez-Burruezo A, Fita A and Prohens J (2009). A primer of genetics and plant breeding, Ed. Universitat Politècnica de València, Valencia, Spain.

50. Rodríguez-Burruezo A, Prohens J, Roselló S and Nuez F (2005). "Heirloom" varieties as sources of variation for the improvement of fruit quality in greenhouse-grown tomatoes. J. Hort. Sci. Biotechnol. 80:453-460.

51. Rodríguez-Burruezo A, Raigón MD, Prohens J and Nuez F (2012). Characterization for bioactive compounds of Spanish pepper landraces. Acta Hort. 918:537-543.

52. Simmonds NW (2008). Introgression and incorporation. Strategies for the use of crop genetic resources. Biol. Rev. 68:539-562.

53. Singh BK, Sharma SR and Singh B (2012). Antioxidant enzymes in cabbage: Variability and inheritance of superoxide dismutase, peroxidase and catalase. Sci. Hort. 124:9-13.

54. Sotelo T, Soengas P, Velasco P, Rodríguez VM and Cartea ME (2014). Identification of metabolic QTLs and candidate genes for glucosinolate synthesis in Brassica oleracea leaves, seeds and flower buds. PLoS ONE 9:e91428. 
55. Tarazona-Díaz MP, Viegas J, Moldao-Martins $M$ and Aguayo E (2011). Bioactive compounds from flesh and by-products of fresh-cut watermelon cultivars. J. Sci. Food Agric. 91:805-812.

56. Terry L (2011). Health-promoting properties of fruit and vegetables, CABI, Wallingford, UK.

57. Tsao R., Khanizadeh S and Dale A (2006). Designer fruits and vegetables with enriched phytochemicals for human health. Can. J. Plant Sci. 83:773-786.

58. Vrebalov J, Ruezinski D, Padmanabhan V, White R, Medrano D, Drake R, Schuch W and Giovannoni JJ (2002). A MADSbox gene necessary for fruit ripening at the tomato ripening inhibitor (rin) locus. Science 296:343-346.

59. Watada AE, Aulenbach BB and Worthington JT (1976). Vitamins $A$ and $C$ in ripe tomatoes as affected by stage of ripeness at harvest and by supplementary ethylene. J. Food Sci. 41:856-858.

60. Weatherspoon DD, Oehmke JF, Coleman MA, and Weatherspoon LJ (2014). Understanding consumer preferences for nutritious foods: retailing strategies in a food desert. Intl. Food Agribusiness Management Rev. 17:61-82.

61. Willits MG, Kramer CM, Prata RGT, De Luca V, Potter BG, Steffens JC and Graser G(2005). Utilization of the genetic resources of wild species to create a nontransgenic high flavonoid tomato. J. Agric. Food Chem. 53:1231-1236.

62. Williams DJ and Pun S (2010). Glucosinolates in Brassica vegetables: role in bitterness and hence significance. Food Austral. 63:407-412.

63. Wricke G and Weber WE (1986). Quantitative genetics and selection in plant breeding, Walter de Gruyter, Berlin, Germany.

64. Yang J, Meyers KJ, van der Heide J and Liu RH (2012). Varietal differences in phenolic content and antioxidant and anti proliferative activities of onions. J. Agric. Food Chem. 52:6787-6793.

65. Yao Y, Sang W, Zhou M and Ren G (2010). Phenolic composition and antioxidant activities of 11 celery cultivars. J. Food Sci. 75:C9-C13.

66. Yoo KS, Bang $\mathrm{H}$, Lee EJ, Crosby $\mathrm{K}$ and Patil BS (2012). Variation of carotenoid, sugar, and ascorbic acid concentrations in watermelon genotypes and genetic analysis. Hort. Environ. Biotechnol. 53:552-560.

67. Zhang Y, Butelli E, De Stefano R, Schoonbeek H, Magusin A, Pagliarani C, Wellner N, Hill L, Orzaez D, Granell A, Jones JDG and Martin C (2013). Anthocyanins double the shelf life of tomatoes by delaying overripening and reducing susceptibility to gray mold. Curr. Biol. 23:1094-1100. 